\title{
Grand Ducal ambitions and Venetian counter-intelligence. The Tuscan failure in the 1607 attack on Cyprus
}

\author{
Las ambiciones del Gran Ducado y el contraespionaje veneciano. \\ El fracaso de la Toscana en el ataque de 1607 a Chipre
}

\author{
DAVIDE TRENTACOSTE ${ }^{1}$ \\ University of Teramo, Italy/Sorbonne Nouvelle-Paris 3, France \\ dtrentacoste05@gmail.com
}

\begin{abstract}
In June 1607, a Tuscan fleet of about twenty ships and two thousand two hundred men attacked the fortress of Famagusta in Cyprus, with the aim of making it the base for the subsequent occupation of the whole island, which had been in Ottoman hands since 1570. The attack was a total failure: the Tuscan fleet, divided into two parts, did not meet as planned and the Greek inhabitants of the island, who according to Tuscan information should have rebelled, did not. Moreover, the Ottoman garrison was aware of the attack, which meant that the attempt at a surprise attack was in vain. It is clear that, excluding the logistical problem of the fleet meeting up, the enterprise's lack of success was due to a total inadequacy of what we today would call "intelligence". The information in Tuscans' hands did not turn out to be completely correct and they were unable to keep the planned operation secret. However, by contrast, the Venetian intelligence was able to manage the information in its possession in a more cautious way, taking advantage of the
\end{abstract}

\footnotetext{
$\overline{1^{*}}$ I used the term 'intelligence' to refer to all espionage and collection of information (and the ability to handle such information) activities carried out by agents and diplomats of modern era States, according to a consolidated historiographic trend as demonstrated by the following works: Bély, Lucien, Espions et ambassadeurs au temps de Louis XIV, Paris, Fayard, 1990; Preto, Paolo, Iservizi segreti della Serenissima, Milano, Il Saggiatore, 1994; Hugon, Alain, Au Service de Roi Catholique «Honorable Ambassadeurs» et «Divins Espions»: Répresentation Diplomatique et Service Secret dans les Relations Hispano-Française de 1598 à 1635, Madrid, Casa de Velazquez, 2004; Carnicer García, Carlos and Marcos Rivas, Javier, Espias de Felipe II. Los Servicios Secretos del Imperio Español, Madrid, La Esfera de los Libros, 2005; Gürkan, Emrah Safa, "The efficacy of Ottoman counter-intelligence in the $16^{\text {th }}$ century", in Acta Orientalia Academiae Scientiarum Hung, 65, 1 (2012). https://doi.org/10.1556/aorient.65.2012.1.1; Iordanou, Ioanna, Venice's Secret Service. Organizing Intelligence in The Renaissance, Oxford, Oxford University Press, 2019. https://doi.org/10.1093/oso/9780198791317.001.0001
}

\footnotetext{
** This article is a re-working of a paragraph of my $\mathrm{PhD}$ research (still in progress), provisionally entitled "Grand Duchy of Tuscany and Safavid Persia. Information, Politics and Levantine diplomacy in the 17th century" (Granducato di Toscana e Persia Safavide. Informazioni, politica e diplomazia levantina nel XVII secolo).

Currently Ph.D. Candidate at the University of Teramo (Italy), in international joint supervision with the University of Sorbonne Nouvelle-Paris 3/UMR 8041 Centre de Recherche sur le Monde Iranien (CeRMI) (France).
}

Recibido: 11 de mayo de 2020; aceptado: 1 de febrero de 2021; publicado: 31 de marzo de 2021.

Revista Historia Autónoma, 18 (2021), pp. 59-74

e-ISSN: 2254-8726; https://doi.org/10.15366/rha2021.18.003

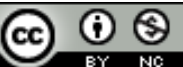


situation effectively.

Through this case study, the article aims to follow the scholarship on information-gathering in the Early Modern Mediterranean world, showing, once again, how important and extensive such networks were. The aim of this short study, which is based largely on archival documentation, is not to deal with the Tuscan raid on the island, but to identify the faults of the Tuscan "intelligence" that led to the misfortunate attack. Moreover, through the analysis of the documents, it is also possible to add some elements to the knowledge about the Tuscan Grand Duke's Levantine network.

Keywords: Cyprus, Grand-Duchy of Tuscany, News and Networks, Early Modern Period, Mediterranean History.

Resumen: En junio de 1607, la flota toscana, compuesta de unos veinte navíos y dos mil doscientos hombres, atacó la fortaleza de Famagusta en Chipre con el objetivo de convertirla en la base para una futura ocupación de la totalidad de la isla, la cual estaba en manos otomanas desde 1570. El ataque fue un completo fracaso: la flota toscana, que había sido dividida en dos partes, no logró reunirse y los habitantes griegos de la isla, que según los servicios de inteligencia toscanos debían de haberse rebelado, no lo hicieron. Además, la guarnición otomana estaba avisada del ataque, lo que diluyó cualquier intento de ataque sorpresa. Dejando de lado los problemas logísticos del encuentro de las flotas, parece evidente que el fracaso de la empresa se debió a un fallo completo de lo que hoy llamaríamos "servicios de inteligencia": la información que obraba en manos de los toscanos resultó no ser enteramente correcta y fueron incapaces de mantener en secreto la operación proyectada. Mientras tanto, los servicios de inteligencia venecianos supieron gestionar la información que poseían de un modo más acertado, tomando ventaja de la situación.

A través del análisis de este caso, al artículo sigue la estrella de los estudios más recientes sobre el intercambio de informaciones en el mundo mediterráneo de la primera Edad Moderna, mostrando, una vez más, la importancia de esas redes. El objetivo de este breve estudio, basado especialmente en documentación de archivo, no es analizar el asalto toscano a la isla, sino identificar los fallos de los servicios de inteligencia toscanos que llevaron al fracaso del ataque. Por otra parte, a través del análisis de los documentos será también posible añadir algunos elementos al conocimiento del que se dispone sobre la red levantina del Gran Ducado de Toscana.

Palabras clave: Chipre, Gran Ducado de Toscana, noticias y redes, historia moderna, historia del Mediterráneo 
1. Introduction

The first decade of the 17th century was a period of intense activity for the diplomacy and foreign policy of the Grand Duchy of Tuscany. Ferdinando I had great ambitions for his state in the Levant: the fleet of the Order of the Knights of St. Stephen terrorized the waters controlled by the Ottoman Sultan, and the possible alliance with Persia seemed to provide Tuscany with a powerful ally capable of facing the Ottoman Empire on equal terms ${ }^{2}$. The latter, in those same years, was shaken by numerous revolts which, together with the war that broke out with Persia in 1603 , seemed to undermine its ability to react in case of a further attack by a European State ${ }^{3}$.

It was in this context that the Grand Duke Ferdinando decided to attempt the conquest of Cyprus, which would then become the ideal base for further Ottoman operations in the Syrian-Lebanese area ${ }^{4}$. Jacopo Riguccio Galluzzi, in his work entitled: Istoria del granducato di Toscana sotto il governo della casa Medici, described the attempt made by Ferdinando to conquer the island in this way:

La conquista di Cipro parve al Gran Duca la più conforme e vantaggiosa alla esecuzione del piano immaginato per la Sorìa, e qualche segreta intelligenza che si teneva in Famagosta fece risolvere la sorpresa di quella Piazza. I Greci aveano promessa di sollevarsi in numero di seimila e coadiuvare l'espugnazione di quella Piazza, da cui dovea dipendere la conquista dell'isola. Il Gran Duca allestì otto Galere e nove fra Galeoni e Bertoni, vi imbarcò sopra duemiladugento soldati tra Italiani e di altre Nazioni e una notabile quantità di armi e di munizioni. Il Marchese Francesco dei Monte ebbe il comando di

\footnotetext{
"On the ambitious "eastern policy" of Grand Duke Ferdinando I, see Uzielli, Gustavo, Cenni storici sulle imprese marittime e coloniali di Ferdinando I granduca di Toscana, Firenze, Spinelli, 1901; Tamborra, Angelo, "Gli stati italiani, l'Europa e il problema turco dopo Lepanto", in Biblioteca dell'Archivio Storico Italiano, XIII, Firenze, Leo S. Olschki Editore, 1961; Brege, Brian, "The advantages of stability: Medici Tuscany's ambitions in the Eastern Mediterranean", in Nicholas Scott, Baker \& Maxson Brian Jeffrey (eds.), Florence in the Early Modern World, London-New York, Routledge, 2019, pp. 263-280; Brege, Brian, "Making a New Prince: Tuscany, the Pasha of Aleppo, and the dream of a New Levant", in Francesco Freddolini \& Marco Musillo (eds.), Art, Mobility, and Exchanges in Early Modern Tuscany and Eurasia, New York-London, Routledge, 2020, pp. 19-32. For a quick (and outdated) overview of Tuscan-Persian relations, see Pontecorvo, Virgilio, "Relazioni tra lo Scià 'Abbās e i Granduchi di Toscana Ferdinando I e Cosimo II", in Atti della Accademia Nazionale dei Lincei, Serie 8/4 (1949), pp. 157-82.

${ }^{3}$ On the anti-Ottoman revolts in the first decade of the $17^{\text {th }}$ century, see Griswold, William J., The Great Anatolian Rebellion, 1000-1020/1591-1611, Islamkundliche Untersuchungen, vol. 83, Berlin, Klaus Schwarz Verlag, 1983; Barkey, Karen, Bandits and Bureaucrats. The Ottoman Route to State Centralization, Ithaca-London, Cornell University Press, 1996, passim; Faroqhi, Suraiya N., (ed.), The Cambridge History of Turkey. Volume 3. The Later Ottoman Empire, 1603-1839, Cambridge, Cambridge University Press, 2006, pp. 91, 191-192. https://doi. org/10.1017/CHOL9780521620956; White, Sam, The Climate of Rebellion in the Early Modern Ottoman Empire, Cambridge, Cambridge University Press, 2011, pp. 163-186; Özel, Oktay, "The Reign of Violence: The Celalis c. 1550-1700", in Woodhead, Christine (ed.), The Ottoman World, London, Routledge, 2011, pp. 184-202.

${ }^{4}$ The occupation of Cyprus would also give Ferdinando the title of King of Cyprus, raising him above the other small Italian potentates. This would also create great problems with the Duke of Savoy since he was the legitimate holder of that title thanks to dynastic marriages. On this, see Oresko, Robert, "The House of Savoy in search for a Royal Crown in the Seventeenth Century", in Oresko, Robert \& Scott Gibbs (eds.), Royal and Republican Sovereignty, Cambridge, 1997, pp. 272-350; Caccamo, Domenico, "I doni diplomatici del granduca Ferdinando I', in Caccamo, Domenico (ed.), Roma, Venezia e l'Europa centro-orientale. Ricerche sulla prima età moderna, Milano, Franco Angeli, 2010, pp. 327-351.
} 
detta armata, la quale soffri la disavventura di sbandarsi per il viaggio. Ciò fu causa che non potendo operare col suo intiero vigore nel primo attacco, e non trovando nei Greci quella disposizione a sollevarsi che aveano promessa, fu necessario il ritirarsi con qualche perdita. ${ }^{5}$

Although brief, Galluzzi's account provided a pretty accurate description of how the events had unfolded. The Tuscan army was not able to operate in its entirety, thus making the attack was too weak. To this fact was added the problem that the Greek population, which was supposed to support the Tuscan army, did not rebel as they had promised ${ }^{6}$. Even if Galluzzi did not report it, another problem that the Tuscans had to face was the lack of the "surprise effect" with which they thought to attack: The Ottoman garrison was indeed waiting for their assault. The latter one had been warned by the Venetians, who believed they were the only Europeans with rights on the island, and who consequently viewed negatively any foreign interference in an area of the Mediterranean they considered to be their own. The Venetians had learned of the Tuscan intentions in advance and thanks to their experience in handling information to their advantage, they managed to keep the Grand Duke unaware of their manoeuvres against him. In short, the Tuscans were unable to preserve the secrecy of the operation and to prevent actions by hostile States.

The early Modern Age was, as is well known, the golden age of espionage, thanks also to the increasing consolidation of states and postal systems ${ }^{7}$. The ability to gather and, above all, use information supplied by European agents was developing strongly and the European courts, and the Italian ones in primis, were constantly receiving a large flow of news ${ }^{8}$. However, handling updates was not always easy, and the lack of a real ability to deal with it could have devastating effects. This paper seeks to focus attention on the importance and impact that intelligence work could have on the outcome of military operations.

Starting from the studies already carried out on the Cyprus enterprise, and integrating them with material preserved in Roman and Florentine archives and largely unpublished, this article tries to show how the causes of the Tuscan military failure are to be attributed more to "intelligence" problems than to the incompetence of the commanders in the field.

As I hope to demonstrate with this analysis, the episode fits perfectly into the branch of studies exemplified by Filippo De Vivo's work. The capacity shown by the Venetian Senate

\footnotetext{
${ }^{5}$ Cf. Galluzzi, Jacopo Riguccio, Istoria Del Granducato Di Toscana Sotto Il Governo Della Casa Medici. XI Volumes, Firenze, 1781, III, pp. 160-161. The various transcriptions of the passages I have quoted, both in the footnotes and in the text, are given as they are written in the documents I have consulted, with their punctuation and abbreviations not altered.

${ }^{6}$ About the raid on Cyprus, see Hadjanastasis, Marios, "Corsair Tactics and Lofty Ideals: the 1607 Tuscan Raid on Cyprus", in Walsh, M. (ed), City of Empires: Ottoman and British Famagusta, Cambridge, Cambridge Scholars Publishing, 2015, pp. 22-36; Acipinar, Mikail, "Ferdinand I's Eastern Mediterranean Policy and the 1607 Attack of the Tuscan Navy on Famagusta", Tarih Incelemeleri Dergisi, XXX / 2 (2015), pp. 357-384.

${ }^{7}$ Carnicer, García and Marcos Rivas, Javier, Espias de Felipe II... op. cit., pp. 13-26; Varriale, Gennaro, Arrivano li Turchi. Guerra e Spionaggio nel Mediterrneo (1532-1582), Novi Ligure, Città del Silenzio, 2014, p. 29.

${ }^{8}$ Not only the Europeans, but also the Ottomans had an efficient intelligence system. In this regard, see Gürkan, Emrah Safa, "The efficacy of Ottoman... op. cit., pp. 1-38.
} 
in handling information - an ability due to the experience gained over centuries of collecting, preserving and manipulating information - is paradigmatic of what De Vivo already outlined in the introduction of Information and Communication in Venice, and which is then deepened in the course of his text, with regard to secrecy, communication, circulation of news and its political use. The issue of Tuscan failure in Cyprus, if it is considered according to a microhistorical approach, can reveal and clarify the workings of some of the mechanisms of the Venetian information and political machine, as well as the "weaknesses" of the Tuscan one. Such deficiencies may also have been common to States other than Venice, and so this could serve as a model for the study of other States in early $17^{\text {th }}$ century Italy as well ${ }^{9}$.

\section{News about Cyprus}

The Grand Duke's diplomatic and war machine was probably set in motion by the news from the Levant, which painted a picture of the Ottoman situation that was particularly encouraging for the Tuscan ruler. His information network was strongly established in the major Italian centres: Venice, Rome and Naples, and it had ramifications also in the main Levantine cities such as Constantinople, Aleppo and Alexandria ${ }^{10}$. In addition, Ferdinando also had two secretaries paid specifically to keep him up to date on issues concerning Cyprus, Lebanon and Syria ${ }^{11}$. However, the most important city in this network of information collection remained Venice: a city through which, thanks to its eastern territories in direct contact with the Ottoman

\footnotetext{
${ }^{9}$ On this matter, see De Vivo, Filippo, "Microhistories of Long-Distance Information: Space, Movement and Agency in the Early Modern news", Past and Present, 242, 14 (2019), pp. 179-214. https://doi.org/10.1093/pastj/ gtz042

${ }^{10}$ On Tuscan news networks, see Varriale, Gennaro, Arrivano li Turchi... op. cit.; Varriale, Gennaro, "Avvisi del Levante a Firenze. L'informazione sul Turco alla corte di Cosimo I de' Medici", in Caroscio, M. \& M. Arfaioli (eds.), The Grand Ducal Medici and the Levant, Brepols, 2016, pp. 33-44; Barker, Sheila, "Secret and Uncertain': A History of Avvisi at the Court of the Medici Grand Dukes", in Raymond, Joad \& Noah Moxham (eds.), News Networks in Early Modern Europe, Boston-Leiden, Brill, 2016, pp. 716-738. https://doi. org/10.1163/9789004277199 032. On European informative systems and networks in general, see Infelise, Mario, Prima dei giornali. Alle origīini della pubblica informazione, Roma-Bari, Laterza 2002; Infelise, Mario, "Sistemi di comunicazione e informazione manoscritta tra '500 e '700', in Messerli A., \& R. Chartier (eds), Scripta volant, verba manent. Schriftkulturen in Europa zwischen 1500 und 1900. Les cultures de l'écrit en Europe entre 1500 et 1900, Basel, Schwabe Verlag, 2007, pp. 15-37; Infelise, Mario, "News networks between Italy and Europe", in Dooley, B. (ed.), The Dissemination of News and the Emergence of Contemporaneity in Early Modern Europe, Farnham, Ashgate, 2010, pp. 51-67 2010; Infelise, Mario, "La circolazione delle notizie nell'Italia moderna", in Luzzatto, S. \& G. Pedullà (eds.), Atlante della letteratura italiana, Torino, Einaudi, vol. II, 2011, pp. 459-465; Petitjean, Johann, L'intelligence des choses: une histoire de l'information entre Italie et Méditerranée (XVIe-XVIIe siècles), Roma, Ecole française de Rome, 2013.

${ }^{11}$ In a letter of 1613 sent to Grand Duke Cosimo II, the Maronite Bishop of Cyprus stated that his father Ferdinando kept two secretaries paid specifically to inform him about Cyprus, Lebanon and Syria: “[...] E perché al tempo del mio predecessore erano dal Serenissimo Granduca Ferdinando di felice memoria tenuti a sue spese due secretarij per avviso delle cose dell'Oriente; ora io voglio per l'avvenire a proprie spese, per honor dell'Altezza Vostra Serenissima tenere tuttavia due, acciò sia ella raguagliata de' successi di quei paesi [...]". Cf, Archivio di Stato di Firenze (hereafter ASFi), Mediceo del Principato (MdP), vol. 4280, f. $101 r$.
} 
Empire and its vast network of spies and informers, it was possible to know everything that happened in the Levant ${ }^{12}$.

Although possible action against the Ottomans had always been in the Grand Duke's plans, the moment when the idea of an attack on Cyprus began to circulate seriously can be traced back to the months when the courts of Florence and Rome were visited by the Persian Embassy led by Sir Anthony Sherley, and the possibility of an alliance with Persia seemed very real ${ }^{13}$. On that occasion, the Tuscan ambassador in Rome, Giovanni Niccolini ${ }^{14}$, wrote to Florence that he had received a proposal from the Pope on the possibility of attempting to reconquer Cyprus by arming some 50 or 60 galleys together with some allies ${ }^{15}$. Niccolini, who knew well the means available to his lord, responded to the Pope's proposal in a diplomatic manner, saying that an attack on Cyprus could be too hazardous and, perhaps, it was better to attack a smaller island like Rhodes ${ }^{16}$. Then, he said to have the impression that Pope Clement VIII was talking to him because he hoped to be able to carry out some kind of enterprise against the Ottomans without having to resort to the help of the Spanish or the Venetians. In the letter, in particular, he expressed the consideration that they would never move against the Sultan, at least until they had really seen him in difficulty ${ }^{17}$.

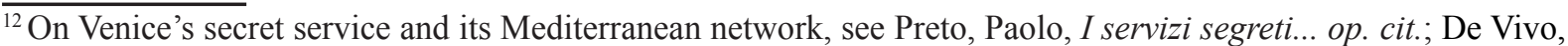
Filippo, "Paolo Sarpi and the Uses of Information in Seventeenth-Century Venice", in Media History, 11, 1 (2005), pp. 37-51. https://doi.org/10.1080/1368880052000342406; De Vivo, Filippo, Information and Communication in Venice. Rethinking Early Modern Politics, Oxford, Oxford University Press, 2007. https://doi.org/10.1093/ acprof:oso/9780199227068.001.0001; Dursteler, Eric, "Power and Information: The Venetian Postal System in the Mediterranean, 1573-1645", in From Florence to the Mediterranean: Studies in Honor of Anthony Molho, Florence, Olschki, 2009, pp. 601-623; Rota, Giorgio, Under two Lions. On the Knowledge of Persia in the Republic of Venice (ca. 1450-1797), Wien, Verlag der Österreichischen Akademie der Wissenschaften, 2009; Iordanou, Venice's Secret Service... op. cit.

${ }^{13}$ The diplomatic expedition left Persia in the summer of 1599 and arrived in Germany in 1600 after passing through Muscovy and circumnavigating Scandinavia. From Germany it passed through Italy in early 1601 and reached Florence in March and Rome in April. For an overview of the Persian Embassy of 1599-1601: Babinger, Franz, Sherleiana, Berlin, Reichsdruckerei, 1932; Davies, David W., Elizabethans Errant, Ithaca, Cornell University Press, 1967; Alonso, Carlos O.S.A., "Embajadores de Persia en la Cortes de Praga, Roma y Valladolid (16001601)", in Anthologica Annua 36 (1989), pp. 11-271; Gil Fernández, Luis, El Imperio luso-español y la Persia safavida. Vol. I, 1582-1605, Madrid, Fundacion Universitaria Espanola, 2007.

${ }^{14}$ On Niccolini, see Zagli, Andrea, "Niccolini, Giovanni”, Dizionario Biografico degli Italiani (hereafter DBI), 78, 2013. «http://www.treccani.it/enciclopedia/giovanni-niccolini (Dizionario-Biografico)/» [accessed on $27 / 02 / 2020]$.

15 "La S.tà Sua nel trattare delle cose de Turchi, et della buona occ.ne che sarebbe hoggi per i disordini loro di fare qualche progresso, mi soggiunse, che haveva qualche volta pensato, che se ci fusse stato in ordine pur 50 ò 60 galere bene armate, che sentita insieme la disposizione di molti popoli delli stati del Turco, i quali pare, che tutti habbino dal maggiore al minore nuove opinioni, che quell'imperio, et quella casa ottomana habbia da cominciare à declinare, che crederebbe S. S.tà fusse facil cosa à ripigliare Cipri, et d'arrivare fino alle castella, aggiungendo la S.tà Sua, che haveva ancora qualche volta pensato, et che di questo io ne scrivessi à V.A., che mettendosi insieme le galere di V.A., quelle di Malta, le di S. S.tà, et qualche altra, che quest'altro anno, poiche questo non è più a tempo, si sarebbe possuto senza li spagnuoli fare qualche impresa". Cf. ASFi, MdP, vol. 3317, ff. 464v-465r.

16 "Risposi, lodando i pensieri di S. S.tà, che per fare l'impresa di Cipri, come S. S.tà haveva detto, queste forze sole talvolta non sarebbono state bastanti, ma che si sarebbe ben possuto disegnare sopra qualche isola minore, come Rodi, Negroponte, et simili, et S. Stà replicò, che quando si potesse pigliare se non queste almeno qualche altra isola commoda, et in luogo di passo da offendere il Turco, si sarebbe possuto farvi qualche fortezza, et tenerla per ricetto dell'Armata, da poter poi in altro tempo disegnar qualch'altra cosa d'avvantaggio [...]". Cf. ASFi, MdP, vol. 3317 , ff. $464 v-465 r$.

17 “'....] non bisognava disegnare, che i Ven.ni havessero mai à muoversi, come haveva detto alli ambasc.ri loro hieri nell'audienza, se non quando vedessero, che la fiera fusse quasi che atterrata, soggiungendo che in tal caso all'hora sarebbe stato bene non li volere in compagnia [...]", ASFi, MdP, vol. 3317, 465v.
} 
In any case, Ferdinando had to show an interest in the Pope's invitation since on 7 July 1601 Niccolini wrote to him that the Pope had been very proud to hear that the Grand Duke was very ready to make a sea expedition on his orders. Indeed, the Pope also asked that Ferdinando himself to be the one to suggest something to him $^{18}$. Niccolini continued explaining that His Holiness said he had reliable information from "trusted men" about the precarious defense situation in Cyprus ${ }^{19}$.

The ambassador should act as intermediary between the Pope and the Grand Duke, and his task was to transmit the information collected for the Pope by these unspecified "trusted men" to the Grand Duke. But, what was the information in the hands of the Curia? By comparing Florentine and Roman documentation, perhaps, it is possible to find some answers. In a letter, kept in Rome under the heading 'Florence' in the collection of the Secretariat of State, there is a document which, probably, is the espionage report on which the Grand Duke and the Pope relied $^{20}$. A letter from Cyprus, dated 28 March 1601, sent by a certain "Giovanni" to a "Signor Nepote" (probably Cardinal Pietro Aldobrandini) contained instructions and suggestions on how to best carry out the enterprise and thus free Cyprus from Ottoman dominion. The letter is very long and extremely detailed, with a list of the weapons required and instructions for taking them to Cyprus: three hundred short guns, as many jackets, one thousand spearheads and various tools were needed/requested. It was recommended that they should arrive hidden inside barrels of salted fish on board a French ship, which would not be subjected to a thorough search by the Ottoman guards ${ }^{21}$. I have not been able to do any further research to trace the

\footnotetext{
${ }_{{ }^{18} \mathrm{ASFi}, \mathrm{MdP} \text {, vo. }} 3317$, f. $535 r$.

19 “"...] haveva [the Pope] tali avvisi di persone da prestarli fede che le dicevano, che Cipri stava in termini, che con 30 galere havrebbe creduto si fusse potuto fare qualche acquisto, et ch'il resto delle costiere delle marine fino alle castella erano tanto mal proviste, che con poca più somma di galere delle sopradette harebbe pensato S. S.tà, che si fusse potuto fare qualche cosa di buono: perche in effetto il rispetto dell'obedienza verso il Gran Sig.re era mancato assai, et in quei suoi stati non vi mancavano delle confusioni, che pure hieri il Card.le Dossat, che haveva avvisi diverso Costantinopoli da i ministri del Re di Francia, haveva mostro alla Santità Sua alcune notitie, che confermavano le medesime confusioni, mali ordini, et poca obedienza; intorno alle quali cose io dissi alla S.tà Sua, che harei dato conto all'Alt.za V.ra poiche così lei ordinava", ibidem.

${ }^{20}$ The Secretariat of State's collection/archive contains the correspondence addressed to Rome from the offices of the various nuncios: in this case, the papers come from Florence (Segreteria di Stato, Firenze). Not to be confused with the Nunziatura's collection which is not part of the Secretariat of State's archive, which also contains papers that were sent from Rome to the nunciatures.

${ }_{21}$ "Car.mo et hon. Sig.or Nepote [...]. Vi mando detto mio figliuolo, con ordini di cercarvi tanto che vi trovi, et vi preghi per l'amor di Dio da parte mia et di tutti questi poveri Christiani che si trovano qui alle pene dell'inferno, che vogliate impiegare il favore di tutti i vostri amici et padroni per ritrovar qualche potente prencipe christiano, che voglia farci questa elemosina di liberarci dalla tirannia di questi cani, [...]. Che il principe che farà l'impresa vi mandi con l'infrascritte armi cioè 300 pistole corte, 300 giacche, 1000 ferri da lancia corti, et cento pale di ferro, che siano quadre, longhe un palmo et mezzo et larghe un palmo, et che siano taglienti da tutte le bande, et cento lame di spade di quattro palmi, le quali armi devranno esser nascoste dentro a barili et casse fatte a posta, cioè i barili con quattro fondi, ripieni dalle bande di pesce salato, et che siano cerchiati ben forti, et ben congiunti, perché il salume non guasti le armi; et le casse con doppi fondi, ma malfatte di fuora et mal polite; [...]; avvertendo che poi per passare liberamente è necessario comparir là sopra un vassello francese perché a questi non si da impaccio, anzi sono ricevuti, et accarezzati assai. Tute queste cose sendo in salvo, bisognerà aspettar il tempo della loro quadragesima, che è il mese di giugno, [...]; hora io ho tre grandissime case vicine alle lor moschee, dove si potrà far la massa delle genti, et con l'aiuto di Dio in questo tempo gli assalteremo la dentro et son sicuro che senza offesa de i Christiani gli metteremo tutti in pezzi, [...]; oltre che in tutta l'isola non vi sono più di $\mathrm{m} / \mathrm{x}$ turchi et vi sono più di $\mathrm{m} / 100$ christiani tributarij, [...]; ma il potentato che farà l'impresa è potrà vicino al tempo dell'essecuttione far tenere alcune galere non molto lontane di là, per poter in un subito haver il tutto, si troveranno nell'isola armi per armar m/60 huomini, et vi saranno da m/8 cavalli, [...]. Scritta in Cipro alli 28 di Marzo 1601.
} 
identity of the author, but it is likely that he was a notable of the island or a religious figure of some importance, as he claimed to own several large houses where he could hide weapons and men $^{22}$. However, I managed to find a copy of this letter among documents in the State Archive of Florence, and a copy of it was probably transmitted from Rome through the Papal Nuncio in Florence $^{23}$. In addition to the necessary weapons and stratagems to smuggle them into Cyprus, it was recommended to brought them on French ships, which were free to move around the Ottoman ports. The author of the letter also clearly indicated when to attack, namely in June when the Ottomans would have spent much time in the mosque for "their Lent" (he meant the Feast of Sacrifice, the Eid al-adha). The Ottoman garrison was not large and it would have been possible to overwhelm it easily thanks to the uprising of the Greeks and the surprise effect of the attack. Furthermore, the Sultan could not react quickly because of the various revolts he was facing in his empire at the same time.

In spite of all this information, Ferdinando did not move immediately, probably needing some more certainty. In 1604, some Tuscan ships made an expedition with the aim of carrying out an inspection of the area between Cyprus, Cilicia and Lebanon. The Apostolic Nuncio in Florence immediately informed the Pontiff that, according to the information he had gathered, the Greeks would rebel if some Catholic prince helped them ${ }^{24}$.

In March 1607, that is a few months before the attack, Ferdinando sent his emissaries to negotiate a treaty of alliance with Syrian emirs in revolt against Ottoman dominion ${ }^{25}$. Disguising their true identity, these emissaries made a stop in Cyprus before arriving in Syria. One of these agents was Michelangelo Corai, a Syrian dragoman who, pretending to be a merchant, was received by the governor of the island ${ }^{26}$. In a largely encrypted letter sent to Florence (dated

\footnotetext{
Al vostro servitio, da buon parente Giovanni Catela di Santo Gioscar". Cf. Archivio Apostolico Vaticano (AAV), Segreteria di Stato, Firenze (Segr. Stato, Firenze), vol. 14a, ff. 294r-295v.

${ }^{22}$ Ibidem.

${ }^{23}$ ASFi, MdP, vol. 907, ff. 62r-63v.

24 "Per lettere de 2 di settembre 1604 dalla corte del Serenissimo Gran Duca. Essendo tornati a Livorno alli 30 del passato, i tre galeoni, che hanno scorso per l'arcipelago, sboccando fra Scarpanto et Rodi, et passando a Cavo Celidono in Satalia, ricercato quel golfo, andorno a' Cipri, et di là costeggiando ben da presso tutto il terreno di quell'isola, si ridussero nell'ultima estremità di quel mare, essendo stati a 10 miglia al terreno di Soria, che è fra Alessandretta, et Tripoli, stando fuori per lo spatio di cinque mesi, lo scrivano di ratione, et altri ministri de quali galeoni riferiscono l'avviso, che si contiene qui di sotto. Li greci per tutto, dove siamo stati, mostrano di non potere più sopportare il governo tirannico de i Turchi, et di desiderare, che i Christiani s'unischino et con mettere loro l'arme in mano tentino qualche segnalata impresa et dicono, che tutte quelle piazze de $\mathrm{i}$ Turchi sono mal guardate et mal munite, et spereriano facile ogni impresa hora che hanno un signore giovanetto, et senza governo, dicono ancora d'havere carestia in tutte quelle provincie". Cf. AAV, Segr. Stato, Firenze, vol. 15, f. $243 r$.

${ }^{25}$ On the negotiations between Tuscany and the Syrian emirs, see Carali, Paolo, Fakhr ad-din 2 II, principe del Libano, e la corte di toscana 1605-1635. Vol. I. Introduzione storica - documenti europei e dcumenti orientali tradotti. 2 Volume, Roma, Reale Accademia d'Italia, 1938, vol. I; Diaz, Furio, Il Granducato di Toscana. I Medici, Torino, Utet, 1976, p. 291; Griswold, William J., The Great Anatolian Rebellion... op. cit., pp. 78 et seq.; Brege, Brian, "Making a New Prince...op. cit.

${ }^{26}$ The Syrian dragoman was named Michelangelo Corai (Fathullah Qurray), and was sent to Syria together with Ippolito Lioncini (Knight of St. Stephen) to negotiate an alliance with the Emir of Aleppo 'Alī Jānbūlād. In the following years Corai acted as ambassador for the Grand Duke of Tuscany at the Persian court. On Michelangelo Corai, see Federici, Federico, "A Servant of Two Masters: The Translator Michel Angelo Corai as a Tuscan Diplomat (1599-1609)", in Federici, Federico M. \& Dario Tessicini (eds.), Translators, Interpreters, and Cultural Negotiators. Mediating and Communicating Power from the Middle Ages to the Modern Era, London, Palgrave Macmillan, 2014, pp. 81-104.
} 
$1^{\text {st }}$ March), the dragoman provided Ferdinando with a report describing his meeting with the pasha of the island and the questions the latter had asked him in an attempt to discover whether he was a western spy. The curious thing about this episode is that, according to Corai, during the meeting the pasha's secretary entered the room and briefed his master about the riots in Cyprus. But instead of communicating in a low voice, again according to Corai, the secretary did so at such a volume that Corai could hear everything. ${ }^{27}$ Corai also claimed to have visited the island's bishop, who stated that the Greeks would rebel if a Christian prince helped them, but also that the Venetians could not be trusted. In the light of how things would turn out, this last warning sounded prophetic. Anyway, the report confirmed what had been known for some time in Tuscany, i.e. that the moment was propitious thanks to the ongoing revolts and the war against the Persians: the Ottomans would not be able to offer real resistance ${ }^{28}$. After two months preparation, the Tuscan fleet set sail for the Levant.

\section{The intelligence work}

As the attack on Cyprus approached, the Grand Duke ordered his ambassador in Venice to find out what the Venetians knew and what their opinion was about the preparations of the Tuscan fleet. In fact, it was essential that the Venetians remain unaware of Ferdinando's intentions, because, first of all, they still considered Cyprus their own possession. And secondly, because the Venetian government feared that if the Tuscans succeeded in an enterprise such as the conquest of Cyprus or some other place in Lebanon - all too close to Syria - then they would be able to divert trade to Livorno, ousting Venetian merchants from the rich traffics that left for Europe from Cyprus ${ }^{29}$. Moreover, the French did not like the idea that the Tuscans

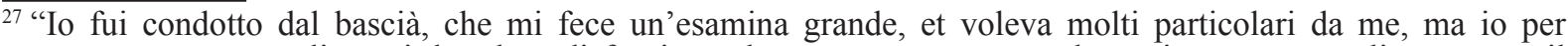
esser mercante, non gli seppi dare la sodisfazzione che cercava, et mentre che ragionava meco gli comparve il maiordomo maggiore et segretamente gli disse esser vera la ribellione de' 1500 Turchi che di nuovo s'erano uniti con i Christiani, né disse si piano che io non intendessi ogni cosa, onde io viddi il bascià molto conturbarsi, che fu la cagione che più tosto mi licenziò, che io andassi à fare i fatti miei. Intesi ancora esser vero che un turco rinnegato de' principali s'è unito con forse 100 Christiani del paese, et con un caramussale sian partiti di notte in gran diligenza alla volta di Malta, per passare, secondo che si dice, in Spagna. Insomma tutta l'Isola è sottosopra. Io andai al porto né trovai barca à proposito. Passai ancora à Nicosia, per accertarmi meglio delle nuove, et trovai esser verissime. Visitai ancora il Vescovo de Greci, il quale m'aperse gran cose, la somma del quale è, che molto confidano in V.A. ma perche non hanno persone, che venghino à trattar con lei, non possono scoprire il facil modo che hanno di far perdere tutto il paese, et uscir di sotto à tanta tirannia, confessando che de Veneziani non si debbono fidare, per esser troppo affezzionati al Turco, et che il Re di Spagna che potrebbe assai è per loro troppo lontano, sì che V.A. sola li potrebbe consolare [...]”. Cf. ASFi, MdP, vol. 4275, ff. 58r-59r.

${ }^{28}$ The Nuncio in Tuscany wrote to Rome that, according to the information in his possession, the Grand Duke thought that the garrison of Famagusta was not numerous and that therefore his conquest would not be difficult. See AAV, $F B$, II, vol. 302, f. $210 r-211 v$.

${ }^{29}$ This was in fact the greatest concern of the Venetians about the ambitions of Ferdinando in the Levant. In a document of 1609 from Venice, and addressed to Rome, it was written that despite the defeat of 1607, in Venice there was the fear that the Tuscan fleet would retry the conquest of Cyprus and that if it succeeded, the Grand Duke would drive the Venetians out of trade with the East: "Più che mai bollono senz'altra resolut:ne fin hora le
} 
might carry out actions that could damage their interests in the Levant ${ }^{30}$. In addition, while the Venetians maintained good neighbourly relations with the Sultan, on which depended their free trade and therefore economic prosperity, the French were linked to the Ottomans by an alliance at least since the first half of $16^{\text {th }}$ century, and they would not welcome the intrusion of a third party into Eastern affairs ${ }^{31}$.

The Tuscan fleet left in May 1607 at the same time that theTuscan ambassador arrived in Venice. By the way, Asdrubale Barbolani ${ }^{32}$ tried to find information for his master about the movements of the grand ducal ships ${ }^{33}$. He had not succeeded in penetrating "intrinsic" - secret - information, but reported that in Venice it was not considered possible that the Grand Duke really intended to attack Cyprus, a place considered a prey too out of reach for Tuscan forces.

Even in Constantinople, it seemed more plausible that the Tuscan fleet had as its objective the galleys that brought the Egyptian tributes to Constantinople ${ }^{34}$.

At the beginning of June, Barbolani was still unable to get clear details about what they knew in Venice about Tuscan ships:

\begin{abstract}
Del senso che habbiano questi sig.ri in materia della galere et bertoni mandati fuori da V.A., ho procurato sapere il certo di continuo, ancorche io reputi difficiliss.o à penetrar l'intrinsico loro in tali occ.ni, et ho anco cercato di scoprirlo per via d'amici et mezzi, che ho creduto posserlo fare, senza mai trovar niss.o che per relatione, notitia o discorso mi habbia detto che vi habbiano o possino haver buon senso mai, et maggiorm.te hora che non si sente che siano restati interam.te sodisfatti dell'A.V. [...]. L'amb. Re di Francia [...], nel fine si entrò negli affari di queste galere et bertoni di V.A., et dopo haver accennato le cause per le quali non possino piacere qui queste attioni, connumerando l'irritatione de Turchi a guerra, il risvegliarli ad esser diligenti nel guardar le piazze loro et
\end{abstract}

considerationi che queste armate si di Toscana, come di Spagna, spese per la p.a si crede che la sia per tentare l'impresa di Cipro, così della $2^{\circ}$ pare che no' si dubiti ch'ella no' sia per spalleggiare la'altra e forse in un med.o tempo tentare qualche altra impresa; onde vanno pensieri attorno per quanto si sempre fino di combattere per impedire si fatti disegni, no' potendo opprimer quanto qui premerebbe quando costoro s'impadronissero di quel Cipro, che la Rep.ca pretende esser sua. Oltre che stimerebbe che quella isola in mano d'altri potrebbe levar a Venetia il commercio della Soria, e dell'Egitto, et transferirlo tutto a Livorno co' danno inestimabile del pubblico e del privato nella città di Venetia. [...]. Di Venezia, 23 giugno 1609”, AAV, Fondo Borghese (FB), Ser. II, vol. 52, f. $64 r-v$.

${ }^{30}$ Further on, in the same letter, it was written that even the Duke of Savoy did not welcome the possibility of the conquest of Cyprus by Ferdinando. The reason was related to the question of the title of King of Cyprus, which I have already mentioned.

${ }^{31}$ As reported in the 1601 report cited in the text, French ships were in fact allowed free trade without very strict controls by the Ottoman authorities. On Franco-Ottoman alliance, see Poumarède, Géraud, "Justifier l'injustifiable: l'alliance turque au miroir de la chrétienté (XVIe-XVIIe siècles)", in Revue d'histoire diplomatique, (1997), pp. 217-246; Garnier, Èdith, L'Alliance impie. François Ier et Soliman le Magnifique contre Charles V, Paris, Editions du Félin, 2008; Isom-Verhaaren, Christine, Allies with the infidel. The Ottoman and French Alliance in the Sixteenth Century, London, I.B.Taurus, 2013.

${ }^{2}$ On Asdrubale Barbolani, see Cantagalli, Roberto, "Barbolani, Asdrubale", in DBI, 6 (1964). «http://www. treccani.it/enciclopedia/asdrubale-barbolani \%28Dizionario-Biografico\%29/» [accessed on 27/02/2020].

33 "Delle galere et altri vascelli che manda fuori V.A. si sentono diversi discorsi, et infine $\mathrm{i}$ più la danno in altri luoghi cioè Rodi per tenerla, ò bracci[o] di Maina per sollevare i greci, asserendo Cipri impossibile à tenere, et anco Scio, et altri luoghi inutili, et in intrinsico non so come qui piaccia”. Cf. ASFi, MdP, vol. 3000, f. 106v.

34 "Di Costantinopoli 30 maggio 1607. [...] Alla Porta non si tiene tanto sicuro che il Ser.mo Granduca mandi l'armata per l'impresa di Cipri quanto che si stima che vada ad incontrare il tributo del Re che se ne viene dal Cairo et per tentar qualche altra impresa [...]". Cf. ASFi, MdP, vol. 4277, f. $453 v$. 
fortificare, in tener più sodisfatti et con più fino i loro vassalli, in dargli occ.ne di levar varie contro la Rep.ca, il danno et le difficultà che ne veniv.o al traffico e mercantie a mercanti et all'entrate pubbliche. [...]. Che trattandosi (come si tiene per certiss.o facendosene anco scommesse pubbliche) del pari l'impresa di Cipro, possino nascere (succedendo bene) disturbi per titoli e preminenze et pretensioni, et si male rovina di quei popoli et dell'armata, se segua semplice incursione et depredatione i luoghi, non gli può piacer mai et maggiorm.te hora che hanno una armata in mare et perciò risonerà tanto più a Cost.li et s'indusse infine a dirmi l'amb.re perche io lo rappresentassi à V.A., che saria forse assai meglio applicare il pensiero alle cose di Barberia accennando Algeri et luoghi vicini [...]; et ritornando a parlare delle galere et bertoni, mi disse che più communemente si crede che non habbiano a fare altri effetti che scorrerie et depredationi, et se si fermasse il piede, non può esser senza spesa, travagli, pericoli et disgusti propri et d'amici et poca sicurezza quando non peraltro per la poca fede et fermezza di quelle nationi. Di questi discorsi fattimi dall'amb.re non sono stato senza pensiero che gli possa esser stata somministrata materia et occ.ne forse di fargli con me, et per questo gli ho riferiti, et anco perché son simili à i discorsi che se ne fanno ogni dì da ogni sorte di persone, trattandosi di questo più che d'altro. ${ }^{35}$

According Barbolani's words, if the Cyprus enterprise had indeed been the objective of the Grand Duke's ships, although considered improbable, was very badly viewed not only by the Venetians, but by the Ottomans. The King of France himself did not seem particularly favorable to the enterprise, according to the words of his ambassador, to the point that the Tuscan one almost had the impression that the arguments against the Cyprus enterprise had been constructed on purpose to discourage it.

On $16^{\text {th }}$ June, although some rumors, Barbolani wrote that Tuscan ships were heading towards Cyprus, the Venetian government still seemed not to believe in this possibility, stating that such an enterprise could not be carried out by the Tuscans without help ${ }^{36}$.

On 23th June (the day before the attack), the ambassador wrote to the Medici court that, among other things, in Venice many theories and bets were being made about the objective of the Tuscans. Besides this, Niccolini said he had the impression that he always had other people's eyes on $\mathrm{him}^{37}$. Apart from feeling observed, it is clear that the ambassador felt the pressure of being an agent of a State which at that time was strongly felt as a rival by Venice. Even though, he had not only the thankless task of gathering information about what the Venetian authorities

\footnotetext{
$\overline{{ }^{35} \mathrm{Cf} . \mathrm{ASFi}, M d P}$, vol. 3000, ff. $119 r-120 v$.

${ }^{36} \mathrm{Ivi}$, ff. $124 r-125 r$.

37 "Quel di che più si parla che d'altra cosa è de navilij et arme mandate fuori da V.A. credendosi che habbiano pensiero in Cipro, ò Morea con intelligenza tale che possino fare effetto, dal quale possa nascere gravissimo danno e disgusto qui, et che s'intenda con l'armata spag.la et questo duplica il dispiacere per le conseguenze che se ne giudicano, talmente che mi dicino persone sensate et di molta qualità che preme non meno che se fusse un ess.to del turco sotto Corfù et che in essentia può generare gran disgusti fra q.ta Rep.ca et V.A., et sentendosene discorsi infiniti, scommesse, ragioni, et relationi de luoghi et stati di essi se ne parla per ogni sorte di gente adesso molto liberam.te, et a me par d'haver rivolti di continuo gli occhi d'ogniuno adosso". Cf. ivi, f. 130r.
} 
knew, but also to talk to dignitaries who, as can be seen from these dispatches, were not at all in agreement with the Grand Duke's foreign policy.

Finally, the attack took place on $24^{\text {th }}$ June and ended with the retreat of the Tuscans: the Ottoman garrison was not caught by surprise and the Greeks did not rebe ${ }^{38}$. However, for weeks nothing was known for sure, and this was due to the Venetians, who had forbidden the dispatch of news to Italy ${ }^{39}$. On $21^{\text {st }}$ July 1607, the ambassador Barbolani explained that he was waiting for news from Gasparo Graziani, one of the Grand Duke's trusted men in Constantinople, but since he had not any answer, he feared something had happened to him ${ }^{40}$.

\section{Reasons for the failed attack}

In late August, information began to arrive about the attack. Barbolani warned that letters from Cyprus or Constantinople were expected in Venice ${ }^{41}$, and the first news that arrived in Venice spoke of a success for the Grand Duke's galleys ${ }^{42}$.

Finally, weeks later, reliable reports began to arrive and it was immediately clear that things had not gone as planned ${ }^{43}$. In addition to the logistical problem of the failure of the meeting of the two parts of the fleet, the real problems concerned the Tuscan intelligence. As already mentioned, the Greeks, contrary to what was reported in all the dispatches and avvisi

\footnotetext{
${ }^{38}$ Cf. Diaz, Furio, Il Granducato... op. cit., p. 294.

${ }^{39} \mathrm{ASFi}, \mathrm{MdP}$, vol. 3000 , f. $150 v$.

40 "Di Gasparo Gratiani non ci sono lettere con questo ordinario, et io ho qualche timore che non gli sia occorso sinistro accidente perché un mercante mi ha mostrato questa mattina una lettera in confidenza d'un suo di Costantinopoli con la quale dice che il Bailo ha proibito sotto pene gravissime e fa grandissime diligenze perche da nessuno si scrivano le nuove in Italia, et che sono state prese due spie del Re di Spagna et d'altri Principi guardandosi di esse gran male". Cf. ibidem. Gasparo Graziani was a dragoman of Croatian origin. He began his career as an interpreter for the English ambassador to Constantinople Thomas Glover; later he served as a diplomat for the Grand Dukes of Tuscany (in particular for Cosimo II), the Viceroy of Naples and the Serenissima. For his services, the Venetian government granted him the honorary title of Duke of Naxos. He served as a dragoman at the court of the sultan until he became prince of Moldavia in 1619. In this capacity he allied himself with the Polish-Lithuanian confederation against the Ottomans. In 1620 he was killed by two of his collaborators after the Ottomans' defeat at the Battle of Cecora. See Luca, Cristian, "Influssi occidentali sull'atteggiamento politico di alcuni principi dei Paesi Romeni nei secoli XVI e XVII”, in Quaderni della Casa Romena di Venezia, 2 (2002), pp. 103-119.

${ }_{41}$ "Quel di che si è trattato et tratta più d'ogni altra cosa con voci frequnt.me et diverse secondo le passioni et interessi è dell'accidente occorso in Cipri all'armata di V.A. di che si ha ben qualche relatione, ma non si sa il certo aspettandolo per lettere di Cipri ò di Costan.li et intanto si fano discorsi infiniti. Io non ho saputo che mi rispondere, ne che dire q'ndo men'è stato parlato, et così restringendomi nele spalle, ho mostrato non saperne niente come è vero". Cf. ASFi, $M d P$, vol. 3000, f. $159 r$-v.

42 "Il successo delle galere si S, Stefano à Famagosta, si vien tutta raccontando in diversi modi, sentendosene de $\mathrm{i}$ sinistri, ma per via di mare se ne aspetta certi avvisi correndo voci sinistre [...]". Cf. ivi, f. 167v.

${ }^{43}$ Reports of the attack on Cyprus can be found not only in Florence, but also in Siena ("Impresa di Famagosta: giustificazione dell'Illustrissimo Signore Francesco Del Monte", Biblioteca Comunale degli Intronati, K.II.16, ff. 132-76), in Rome ("Relazione dell'impresa di Cipro", AAV, FB, IV, vol. 280, ff. 14r-15r) and Venice ("Rellatione del tentativo di Famagosta fatto la notte della vigilia di S. Gio. Battista dall'armata di Fiorenza l'anno 1607', Biblioteca Correr, Codice Cicogna, 3182/5, 115b).
} 
of the previous months, did not rebel and the Ottomans did not seem to have been taken by surprise.

A report sent to Rome by the Nuncio in Florence said that of the six thousand Greeks who were reported to have rebelled, only a few people arrived. But also, it was written that one of the Greek elders went to the Tuscan commanders to say that the Greeks would not rebel in support of those few Tuscan men ${ }^{44}$. Apparently, the Greeks either expected a lot more men or, more likely, they did not respect the agreements made because, although they did not know in advance the extent of the Tuscan forces, they did not show up where it was previously agreed.

Nevertheless, the real problem was that the defense garrison had not been taken by surprise. To understand the cause, it is useful to check the correspondence that began to arrive about a month after the Tuscan attack. This news referred to things that had been seen and that had happened several weeks before the date they were received by the Italian courts. A copy of a message sent from Constantinople to Rome, dated $20^{\text {th }}$ August, mentioned a letter received at the Sultan's court stating that the Tuscan general Del Monte had sent a message to one of his relatives in the service of Venice, to tell him that he was leaving for Cyprus with the Tuscan fleet ${ }^{45}$.

It is clear that there had been a leak which allowed the Venetians to immediately alert the Ottoman authorities. The Tuscan Del Monte was the Marquis Francesco Bourbon Del Monte, i.e. one of the commanders of the expedition ${ }^{46}$, while the Venetian one was probably Giovanni Battista del Monte (1541-1614) ${ }^{47}$. In the Florentine archive there is a copy of the letter I mentioned above. This one arrived in Florence several months after the attack:

Essendomi capitate in mano gli originali dell'infrascritte copie di lettere, serenissimo signore, risolsi subito (come fü) mandare con esse Gasparo Graziani à N.P. [V. A.] quale honorai con carico dragomano per obbedire à $\mathrm{i}$

\footnotetext{
44 “[...] se loro [toscani] havevano condotta armata atta a debellare il regno loro si sarrebbono sollevati, ma che per li poca gente, che vedeano esser comparsa, non compliva loro far motivo a rischio d'esser senza speranza di frutto tagliati a pezzi: e soggiungendo i nostri che erano seguitati da bon numero de legni ben armati, et provisti d'ogni cosa necessaria; gli fu risposto che pigliassero la fortezza, che quando l'havessero visti dentro impadroniti, che all'hora si sarebbono smossi et presi l'armi, et datoli ogni altro aggiuto per loro possibile [...]'. Cf. AAV, $F B$, IV, vol. 280 , ff. $14 r-15 r$.

45 “Cost. 20 agosto 1607 da Geronimo Meolo. [...] Appresso questo re si ritrova una lettera di un certo del Monte scritta a quel del Monte Generale de' Venetiani suo parente, dandogli conto che doveva andare in Cipro per servire il Gran Duca all'impresa di quel regno, scrivendogli minutamente il modo; la qual lettera è stata mandata qua dal principe al Bailo con una sua acciò la presentasse al re, nella quale dava conto haver havvistao quel Bassà. Fò ogni sforzo acciò il sig.re Amb.re habbia copia et se s'havrà ne mandarò anco copia a V.S. Ill.ma. [...]". Cf. AAV, FB, IV, vol. 86, f. $339 r$.

${ }^{46}$ On Francesco Bourbon Del Monte, see Inghirami, Francesco, Storia della Toscana. Tome XII, Poligrafia Fiesolana dai torchi dell'Autore, 1843, pp. 320-321; Marchesi, Giorgio Viviano, La galleria dell'onore ove sono descritte le segnalate memorie del Sagr'Ordine Militare di S. Stefano..., Forlì, Per li fratelli Marozzi, 1735, pp. 197-202. In this last-mentioned work there is a further account of the raid against Famagusta.

${ }^{47}$ About the Del Monte family, see Lazzeri, Corrado, "Bourbon del Monte S. Maria", in Enciclopedia Italiana: «http://www.treccani.it/enciclopedia/bourbon-del-monte-s-maria \%28Enciclopedia-Italiana\%29/» [accessed on 06/04/2020]. On the Del Monte in the service of the Grand Duchy of Tuscany, see Orsini, Filippo, "L'Ordine di Santo Stefano e l'Umbria", in Gemignani, Marco (ed.), Atti della giornata di studi Perugia scuole di lingue estere dell'esercito 6 settembre 2013, Pisa, CLD Libri, 2014, pp. 11-45. On Francesco de Monte, see Gamurrini, Eugenio, Istoria genealogica delle famiglie nobili toscane et umbre, 5 Volumes, Firenze, Stampera di Francesco Onofri, 1668-1685, vol. I, pp. 184-186.
} 
cenni suoi havendogli fatto lasciare da parte ogni altro negozio per grave che fusse accio vegga quanto mi siano à cuore li suoi non essendo cosa questa che possa patir dilazione acciò veda quanto si è trattato li giorni à dietro '1 P.N. [A. V.] sendomi mostrati gli originali da huomini dell'istesso Bailo per vederle solamente et io con destrezza ne feci pigliare copia dal mio segretario fin tanto che quell'huomo si trattenne meco à desinare non per altro che per mandargliene assicurandola che se prima le havessi potute havere gliele haverei mandate $[\ldots]$.

Di Costant.li li 16 di ot t.re 1607, Di N. P. 4 Devot.mo Tomaso Glover Amb. re Anglo.

Lettere scritte dal Doge di Venetia del X di giugno 1607 al Signore Ottaviano Bon Bailo in Const.li.

Intendendo dal acclusa quanto la F.N. [Ecc:za V.] vedrà per l'amicizia che è fra la Casa ottomana et noi habbiamo spedito il presente latore di questa a posta acciò facciate su.to intendere al Gran Signore quanto si tratta di fare contro la M.tà Ser.ma del suo Imperatore, dicendogli che habbiamo fatto intendere al bassà di Cipro lavendo mandato una fregata con l're perche proveda à quanto è bisogno per la F.N. [Ecc:za V.] dia al Visire qualche consiglio che vi parra necess. in tal caso et Iddio di mal vi guardi. Di Venezia.

Per non fare tumulto et non scoprire il neg. Et da che banda si ha', non ne habbiamo fatto parola in Senato ma habbiamo voluto scrivere ciò di n'ro pugno.

Cap.lo di l'ra scritta da un S.re del Monte di Livorno all Ill.mo del Monte G'nale de venetiani de 25 maggio.

Partirò fra pochi giorni per serv.e di questa Alt.za alla volta di Cipro et credo che l'impresa riuscirà facilm.te perche il tutto di qua è benissimo apparecchiato. Prima portiamo con noi gran gente, et armi da dare alli greci di quella isola et anco selle per cavalli et andaremo à fare l'assalto à Famagosta dalla banda che le muraglie sono più basse e lontane da sentinelle portando con noi scale fatte proprio à quella misura et dentro sono ancora Christiani et piacerà Iddio che riesca perche andarà poi ad altri luoghi per maggiore imprese. Dai ordinarij. Prego V.A./N.P. non nominarmi con veruna persona per rispetto del mio Re' [probably Pre', i.e. Padrone] et la supplico haver à cuore l'honor mio ne meno con il latore di questa perche non sa quello contenghi la pr'nte l'ra. ${ }^{48}$

The contents of this letter largely answered the questions about what had gone wrong, even without further explanation. It should be analyzed in a little more depth, also in order to understand information issues better.

The letter is divided into three parts: the first one is the introduction where the writer presented the contents of the message and how he managed to obtain a copy of it. The second

\footnotetext{
${ }^{48} \mathrm{Cf}$. ASFi, $M d P$, vol. 4277 , f. $460 r-v$. The letter contains some abbreviations, probably in code, to hide the real addressees of the letter. N. P. corresponds to V.A., Vostra Altezza (Your Highness), F. N corresponds to Ecc.za V., Eccellenza Vostra (Your Excellency). N. P. 4 probably is V.A.S., Vostra Altezza Serenissima (Your Serene Highness).
} 
part is a copy of the communication sent by the Venetian doge to the bailo Ottaviano Bon, in which he referred to the fact that the Republic had warned the Sultan that the Grand Duke would attack Cyprus, inviting him to make the necessary preparations for the defense ${ }^{49}$. It was also added that given the sensitivity of the subject, the Venetian government had decided not to talk about it in the Senate to avoid leaks, and therefore had preferred to write about it to prevent anyone from hearing anything. The last part is instead a copy of the letter - dated May 1607 - sent by Del Monte of the Tuscan army, which was about to leave, to his relative in Venice, and it was probably the message that had alarmed the Venetian Senate. The secrecy with which the latter treated this issue was the reason why Niccolini was unable to obtain news about the Tuscan expedition: Venetians were able to keep secrets, leaving everyone in total ignorance about their help for the Sultan. It is evident that the Grand Duke was not able to do the same, seeing as Del Monte who, just before leaving, thought it as a good idea to warn one of his relatives in the service of a state whose interests conflicted with those of Tuscany. The doubt remains as to whether Del Monte was a traitor or not. While, on the one hand, he wished the enterprise success, on the other hand, he asked his relative not to mention his name and to keep everything secret, since not even the messenger knew the contents of the letter, a sign that he knew he was going against the will of his master.

One last point concerns the identity of the person who sent these copies of the letters to the Grand Duke. This was Sir Thomas Glover, the English ambassador in Istanbul, who made a great effort to obtain copies of these messages, which were to remain secret ${ }^{50}$. This sheds new light on the extension of Grand Duke Ferdinando's information network and his good relations with England.

It showed, therefore, that although everything was benissimo apparecchiato (very well set up) for the expedition, the same could not be said for the secrecy which should have surrounded the operation. The Venetians were able to know well in advance the objective of the Grand Ducal army and they were able to move with great security and, above all, secrecy. The Tuscan "secret services" therefore failed in every respect ${ }^{51}$.

\footnotetext{
${ }^{49}$ He was the Venetian bailo in Constantinople from 1604. See Pasdera, Margherita, "Bon, Ottaviano", in DBI, 11 (1969). «http://www.treccani.it/enciclopedia/ottaviano-bon (Dizionario-Biografico)/» [accessed on 07/04/2020]; Dursteler, Eric, "Ottaviano Bon", in Thomas, David \& John Chesworth (eds.), Christian-Muslim Relations. A Bibliography History. Volume 9. Western and Southern Europe (1600-1700), Leiden-Boston, Brill, 2017, pp. 666670.

${ }^{50}$ On Sir Thomas Glover, see McLean, Gerald \& Nabil Matar, Britain \& the Islamic World 1558-1713, Oxford, Oxford University Press, 2011, pp. 62-3, 82, 97-98.

${ }^{51}$ The Tuscan government was apparently only able to maintain secrecy in Florence. In fact, at the end of May, the papal nuncio in Tuscany wrote to Rome that it was still not clear what the target of the Grand Ducal galleys was, see AAV, FB, II, vol. 302, f. 187v, 28 May 1607. Only on 18 June the nuncio was able to communicate to Rome that the destination of the Tuscans was Famagusta, see ivi, f. $210 r$.
} 


\section{Conclusion}

The logistical error of failing to assemble the army before the attack certainly had the consequence of not convincing the Greeks to rebel: fighting alongside fewer men than they expected, they did not feel ready to risk their lives. However, the strong point of the Tuscan raid was supposed to be the surprise effect, thanks to which the Grand Duke's experienced soldiers could carry out their plan. Unfortunately for them, the Venetians were much better: they managed to make everyone believe that they did not think it was likely that the Tuscans would really attack Famagusta, thus giving a false sense of security to Ferdinando.

The Venetians' experience in controlling and handling information played an important role in this affair. The ability to prevent the Tuscan ambassador from knowing their secrets, the shrewdness in not dealing with "the Cyprus affair" in any spoken manner but only by written missives and, finally, the order not to send ships to Italy that could have brought news to their rivals played a fundamental role in the failure of the Tuscan attack.

In my opinion, there are still two unclear aspects to this affair: the first is what Francesco Del Monte's real intentions were in communicating important information to his 'Venetian' relative; and the second one is why the Venetian ambassador was so careless in showing confidential documents to the English ambassador in Constantinople.

Whatever the reasons, the Grand Duke, although very disappointed, did not lose heart and a few months later his ships attacked and sacked Bona (Annaba) in Algeria, washing away the shame of Famagusta. 